\title{
W'ILLIAN SAYERS
}

\section{DANTE'S VENETIAN SHIPYARD SCENE (INF. 21), BARRATRY, AND MARITIME LAIY}

One of the best loved similes in the Commedia is based on the Arzanà, the Venetian Arsenal or shipyard, where ships for trade and war were built and repaired. Although we are in Inferno, more precisely the fifth zone of Malebolge (Canto 21), within the closed precincts of the imagined or remembered shipyard, life seems busy, orderly and secure, before the contingent life of the sea is again ventured. All comparisons of the conditions and events of hell must be with the real world, and thus, while the simile is intended to illustrate infernal activity, it is also, in a second sense, a reprieve and respite.

Quale ne l'arzanà de' Viniziani

bolle l'inverno la tenace pece

a rimpalmare $\mathrm{i}$ legni lor non sani, ché navicar non ponno-in quella rece chi fa suo legno novo e chi ristoppa le coste a quel che più vïaggi fece; chi ribatte da proda e chi da poppa; altri fa remi e altri volge sarte; chi terzeruolo e artimon rintoppa-: tal, non per foco, ma per divin' arte, bollia là giuso una pegola spessa, che 'nviscava la ripa d'ogne parte. I' vedea lei, ma non vedëa in essa mai che le bolle che 'l bollor levava, e gonfiar tutta, e riseder compressa.

As in the arsenal of the Venetians they boil the viscous pitch in winter to caulk their unsound ships-for they cannot sail then, and instead one builds himself a new ship and another plugs the wales of his that has made many voyages, one hammers (or hacks) at the prow and another at the stern, this one makes oars, that one twists ropes, another patches jib and mainsail; so, not by fire but by divine art a thick tar was boiling 
below there which stuck to the bank on every side. I saw it, but saw in it nothing but the bubbles raised by the boiling and the whole swelling up and settling together again. ${ }^{1}$

Commentators have been puzzled by two aspects of the simile: why the vast panorama of the shipyard subsides into the pool of bubbling pitch ("after such an elaborate vehicle, where is the tenor of the simile?") and how the shipyard and its pitch are relevant to the sinners on the fifth level ("what do grafters and embezzlers have to do ship repair?"). As Richard H. Lansing writes of this "asymmetrical simile":

Not all critics have been happy with this simile. Criticism has been levelled against Dante for his inclusion of details extraneous to the purpose of the simile, which, according to the stated tertium comparationis, consists of conveying an image of the boiling pitch. ${ }^{2}$

Before addressing these two and several related questions, it will be useful to consider briefly the literary background from which Dante extracted his medium of divine punishment and to review some historical facts concerning the Arzana. In the medieval Christian conception of Hell, boiling pitch was one of the conventional means of torturing the bodies and souls of the damned. It is met in the I isio Sancti Pauli, the Irish I'ision of Tuugdal and I'ision of Adomnam, and in Marie de France's L'Espurgatoire seint Patriz. ${ }^{3}$ Biblical antecedents are the land made desolate by Lord's vengeance (Isa. 34.9) and the Daniel story. But in none of these does the pitch take the volume of an entire pool.

Two kinds of pitch were employed in Antiquity and in the Middle Ages. Resin was extracted from pinetrees and boiled to reduce the water content. Later pine pitch would became a major trade item from the Baltic. Bitumen was also extracted from tarpits and more solid deposits and was an important commodity in the Mediterranean basin. Not only is bitumen a telluric product, but like pine pitch it had to be subjected to intense heat to become useful. Thus both underground origins and the attendant heat would lend it a hellish quality, in addition to the very real pain caused to the skin by the hot, viscous, adhesive substance.

Medieval ships were built of green timber and thus, despite carefully assembled seams, warping and leakage were chronic problems. Caulking by driving oakum (Ital. stoppa) between planks and then coating with tar was an important feature of ship construction and maintenance. Mthough tar was exported from Ragusa to central and northern Italy, a major source of bitumen from Antiquity throughout the Middle Ages 
were the tarpits of the Middle East. ${ }^{4}$ It is then not too surprising that Italian words for caulking in the sense of sealing seams between ships' planks with oakum and pitch such as calafatare, calafatura, calafataggio are ultimately of Arabic origin, as, indeed, is the Venetian name Arzana and standard Italian arsenale. 5 Thus it might be assumed that pitch had not only a whiff of the infernal but also of the infidel, reinforcing its appropriateness to figure as a means of punishment in a Christian conception of Hell. The use of boiling pitch as a military weapon on land and sea also reinforced these antagonistic associations. ${ }^{6}$ While important aspects of the legal dimension of seafaring will be explored below, we should note here that seaworthiness was so vital to shipping that requirements were explicitly set out in formal agreements. The contract drawn up in 1210 between the Republic of Venice and crusaders for transport to the Holy Land stipulates: "Que naves vero erunt bene calcate et sarciate in velis, funibus, arboribus et ceteris omnibus." 7 Caulking became one of the specialities of the arzanalotti and there are instances of these skilled workmen being hired from as far away as France and England (Hutchinson 1994:44).

Built in 1104, the shipyard was enlarged in 1303-04, by which time it had a enclosed perimeter two miles in length and high walls surmounted with battlements and flanked by towers (Concina 1988). Dante is believed to have visited Venice during this same decade, when the republic was at the peak of its mercantile power. Perhaps some of the overall plan and architecture of the arsenal, its various buildings with naves, vaulted arches, and covered stretches of water, is reflected in this level of Malebolge with its bridges, ridges, and pool. He could also have seen examples of nautical repair activity (including caulking) on capitols in the cathedral of St. Mark in Venice. ${ }^{8}$ By the time of Dante's assumed visit the government of the republic was legislating standards of ship construction and ship safcty, even when vessels were built under private aegis. ${ }^{9}$ Thus, the Arzanà, like Inferno, was subject to a higher power.

The patron saint of the carpenters of the Arsenal, one of the guilds that included caulkers and oarmakers, was St. Isidore of Chios, whose relics had been acquired by the Cathedral of St. Mark in 1125. Although the frescoes illustrating the vita and translatio of the saint that adorn the Isidore chapel to the left of the main altar post-date the Commedia, it is possible that the poet was aware that Isidore, from Alexandria, was an officer in the army of Emperor Decius and travelled with his fleet to the island of Chios in 251. Denounced as a Christian to Numerius, the commander of the fleet, he was tortured and beheaded when he refused to give up his faith. His body was cast into a well, whose waters later pro- 
duced miracles. Thus, the dead saint thrown into a well of water is neatly, although darkly, mirrored in the sinners submerged in a pool of pitch explicitly linked to the shipyard of which Isidore was a patron saint. ${ }^{10}$

Against this background, let us now address the technical lexicon associated with the work of the shipyard, for which we must imagine ressels under construction, in drydock, or careened over to provide access to the lower hull." ${ }^{11}$ The epic simile incorporates the catalogue device favored by writers of Antiquity and the Middle Ages, so that the various activities of the shipyard are accompanied by no fewer than eight terms for ships, parts and gear: legno, coste, proda, poppa, remi, sarte, terzeruolo, artimon, plus the materials of wood and pitch, the specific actions of plugging (ristoppare), caulking (rimpalmare), hammering or working with an adze (ribattere), and patching (rintoppare), the latter all marked by the repetitive, here restorative, $r$ - prefix. ${ }^{12}$ The list begins with whole ships, then like a cinematic pan moves in detail from hull up to sail, concluding down on the deck level of human activity with oars and rope. Just as the prow and stern together suggest the body of the ship lying between them, the choice of the mainsail and jib (but not the middle-sized mizzen) draws the eye along the upper lines of an imagined ship. These deictic effects, limning both any single ship (a virtual ship) and the shipyard as a whole, stand in sharp contrast to the subsequent, near bidimensional flatness of the pool of pitch. Nonetheless, the boat parts are not functionally linked, do not operate together, and thus, as often happens with catalogues, the items listed acquire near equivalent status, without hicrarchization, all being worked by similar repetitive movements.

On points of detail, Dante's mention of "coste" being caulked has generally been understood to refer to the ribs of a ship's framework, to which planking was then attached in what has been called skeleton construction. But the internal ribs would not have been caulked and it is possible that the poet had in mind the vertical and horizontal wales that reinforced hulls and served as fenders, and were a distinctive feature of Venetian trading ships. The hammering on prow and stern may have been work with an adze to shape timbers, or hammering in nails or other fasteners, as has been generally understood. Caulking, too, involved hammering, but this is less likely in that the conventions of the catalogue device entailed naming each item only a single time.

Ships and boats of several different types were built in Venice and it is perhaps futile or a misreading of the poet's intentions to seek to identify any one type as the object of his description. For example, throughout the thirteenth century oared vessels were generally distinct from those 
with more than a single mast. But early in the following century Venice would make standard the galeazza da mercanzia, a trireme or larger type of oared galley with up to three masts, and thus more sail power, designed specifically for commerce. ${ }^{13}$ Such a ressel would subsume all the features to which Dante calls attention.

Dante was not the first author to catalogue ships or their parts, and if he did not have first-hand acquaintance with related scenes in the Iliad and Odyssey he knew his Virgil well. Here it seems pertinent to recall the effects of Juno's storm on Aeneas's fleet when he left Dido and Carthage. Although Virgil has only the nucleus of a catalogue: "franguntur remi; tum prora avertit et undis dat latus" ("the oars are broken; and then the prow swings round and gives the broadside [to the waves]"; Bk. 1, 104f.), the account of the voyage and tempest scene employ a much fuller nautical lexicon, the greater share of which finds its counterpart in Dante. ${ }^{14}$ Perhaps it is not too far-fetched to suggest that in the Commedia Dante, in one of several nods in the direction of his literary master, is repairing the ships damaged in the Aeneid, just as Virgil is engaged in the repair of the defective vessel that is Dante. ${ }^{15}$

Moving beyond the shipyard simile that opens Canto 21, we may note a number of features specific to this and the following canto, although such a claim could doubtless be made for very many parts of the work. Firstly, Dante and Virgil approach the fifth bolgia "altro parlando che la mia comedia cantar non cura" (21.1f.). Not only is the Commedia explicitly mentioned (one of only two such instances in Inferno), but readers are not privy to the conversation. Later clues, which include Dante and Virgil being of one mind when leaving this bolgia, suggest that they may have been talking of art or Dante's personal situation before the law. ${ }^{16}$ The environment itself is marked, both topographically and symbolically, by the traces of Christ's harrowing of Hell. ${ }^{17}$ Indirectly referring to this unique event, a devil provides the poem's sole means to situate Dante's vision of Inferno in historical time. This level of the pit was also the farthest point in Virgil's prior descent, which he will recall in linguistically marked fashion (see below). Although other keepers of the damned have earlier been metChiron, Geryon, horned demons-Dante will here see his first winged devils as conventionally depicted in popular tradition, all with individualized names, and will for a first time be physically threatened by infernal beings. This may well stand in correspondence with the fact that Dante had himself been charged in 1302 by the city of Florence with barratry (and would have been subject to death by fire), the crime for which the sinners in this bolgia are punished. It has also been noted that the description 
of the punishment for this $\sin$ in a sense escapes the formal constraints of a single canto. Indeed, over two and a half cantos, the sin of barratry receives the fullest treatment in Inferno. The sin and sinners are both anticipated and recalled at intervals nearly equidistant from this narrative moment. ${ }^{18}$ In Canto 13 Piero delle Vigne, Frederick II's chancellor, exculpates himself from the charge of unfaithful service (although re-incriminated by current scholarship), and Canto 33 has a recall of Michele Zanche, of whom Dante will hear in Canto 22.

Against the background of features that give the encounter with the barrators particular relief, we may now return to the question of the expected balance in the two halves of the epic simile which marks Dante's initial perception of this scene of punishment. I contend that the remainder of the two cantos here under consideration is pervaded by nautical and maritime imagery associated with Virgil, Dante, the devils, the sinners, even art, law, and life, which, taken as a conglomerate if not a whole, assumes a volume commensurate with the activity of the Venetian shipyard. That such imagery is not immediately apparent is due to its being folded into the account like the subsiding bubbles of pitch through various devices that vehicle duality, doubling, parallelism, reversal, inversion, etc.-literary techniques formally, if not morally; comparable to the dissimulations of embezzlers, grafters, and other fraud artists. Dante's rhetorical strategy, whose purpose we shall later explore, will be seen to be modelled on the modality of the sinners' prior activities, as recalled by a devil with cruel irony: "Coverto convien che qui balli, sì che, se puoi, nascosamente accaffi” (21.53f.).

First, however, we should address the likely counter-contention that maritime scenes and imagery are everywhere found in the Commedia. ${ }^{19}$ As early as the twenty-second verse of Canto 1 we find a shipwrecked swimmer (Dante) escaping from dangerous waters toward shore. ${ }^{20}$ Then Dante meets Charon smiting reluctant passengers with his oar (Canto 3). Somewhat later hell is likened to a tempest-racked sea (5.28-31). The repair scene of the Arzanà might be thought anticipated in the image of the snapped mast and fallen sails which opens Canto 7, the loosened anchor of 16 , or the simile of sinners as partially beached ships in 17 . We have Virgil identified as "mar di tutto 'l senno" (8.7). Further to the boating on the Styx, there are references to Jason of the Argo, Icarus, and to the waves beneath Seville.

If we consider the thematics and architectonics of the Commedia as a whole, it could even be claimed that the sea voyage, in parallel to that on land, is a fundamental organizing image of the poem. ${ }^{21}$ Students of Dante 
will not be surprised to find cammino or its equivalent in a marine context in all three canticles (Inf. 26.122,22 Purg. 19.23, Par. 13.136-38) or the sailor Ulysses given heroic stature, comparable although in rather different fashion to none save Dante himself (Inf. 26). Ulysses' "varco folle" and his point of farthest exploration into the unknown, the mountain of Purgatory, are recalled in both succeeding canticles (Purg. 19.22ff., Par: 27.82ff.). ${ }^{23}$

Even on the level of detail, seagoing ships are everywhere present. As a single example, the ship is summarized in the lexical pair proda/prora : poppa. Alliteration, assonance, the axial movement from front to back give this double metonym emblematic status. It has $\backslash$ irgilian antecedents (see above) and is first met in the shipyard simile. It returns in more dynamic fashion at the very end of Ulysses' speech ("a la quarta levar la poppa in suso / e la prora ire in giü"; 26.140f.), then recurs in the comparison of Dante to an admiral (Purg. 30.58), when he turns after hearing the first words of Beatrice. Finally, in Paradiso, it is associated by Beatrice with the image of the true course: "... che la fortuna ... le poppe volgerà u' son le prore, / sì che la classe correrà diretta” (27.145-47).

As the most complex machine of the Middle Ages, the ship lent itself to metaphorical extension. The familiar "ship of state" image is given angry expression when Sordello likens Italy to a ship without a pilot caught in a storm (Purg. 6.77). Similarly, the papacy is presented as God's unfortunate ship laden with its ill-fated cargo (Purg. 32.128f.). But it is more fitting to conclude this excursus with Dante's use of the image of the poem as ship, closely tied to the notion of the spiritual voyage. Dante is the shipwrecked swimmer in Canto 1 of Inferno (or ship's boat to Virgil's ship in Canto 23, see below). His improving spiritual state allows his craft at the beginning of Purgatorio to be called "navicella" (1.2). But at a nearly equivalent point in the third canticle Dante's vessel is a much more substantial one:

$O$ voi che siete in piccioletta barca,

desiderosi d'ascoltar, seguiti

dietro al mio legno che cantando varca (2.1 ff.)

Here Dante continues in a voice very like Ulysses'. From the perspective of present concerns and the Venetian Arzanà, it recalls the Doge of Venice on Ascension Day wedding the Serene Republic to the sea, his stately galley, Bucintoro (built at the Arzanà), followed by popular craft. The wedding of the "ascendant" Dante, on the other hand, whose vessel was secular art, was to theological truth. Despite its emphasis on light, maritime imagery continues throughout the remainder of the third canticle $(23.67 \mathrm{ff} ., 25.133,26.62,27.145 \mathrm{ff}$.) and is employed a final time within 
fifty lines of the conclusion of the work, when Dante's wonder at the universal form is likened to Neptune's at the sight of the underwater shadow of the first ship (Par. 33.96).

Let us now return to the question of the deployment of nautical and maritime allusions in Cantos 21-23 and their relevance to barratry. The two cantos, their cast of characters, the events recounted, and the narrative and descriptive style are all under the sign of duality, doubling, and the like: graft, compacts made and broken (with a barrator, with Malacoda), reversals (money turns "no" into "yes"), irony ("furo che Bonturo," 21.41), paradox ("Allor mi volsi come l'uom cui tarda / di veder quel che li convien fuggire," $21.25 \mathrm{f}$, notably early in the canto; cf. the sinner who later dares to emerge when he should stay submerged), oxymoron (the immediately following "paura ... sgagliarda"). Already noted or to be discussed more fully below are the instance of imperfect duality (the apparent loss of second half of the opening simile), the return to a prior state (the repair of ships), coercive, concrete association (pitch, hooks and skin; pece, uncino and their synonyms make countless appearances in the verses), inversion (the newly arrived sinner is the reverse image of the devil carrying him), the combinations of high and low register (the Commedia named at the beginning of a canto that ends with the poem's most vulgar moment, the high incidence of colloquial language, grating rhymes), and of comic but frightening effects in the devils' grotesque antics. ${ }^{24}$

Like the earlier noted thematic markers that give the treatment of the fifth bolgia exceptional status, a concentration of features or instances of a somewhat lesser order authorizes us to scrutinize Dante's vocabulary closely for wordplay or what we might call interlexicality or semantic duality. The simile begins with two Venetisms, "arzanà" and "Viniziani," the poet's ventriloquist voice seeming to come from elsewhere. Early on, the passage is marked by lexical repetition, suggestive of both reiterative shipyard activities and the bubbling pitch, but also a kind of first step toward wordplay or the interaction of otherwise discrete words: vedea/vedëa, bolle/bollor, guarda, guarda (vv. 19-22; for an example of anagram, see below). ${ }^{25}$ Vedere will, in fact, be employed no few than seven times in 28 verses, along with its synonym mirare, as Dante resolutely manoeurres us toward almost exclusively risual perception. ${ }^{26} \mathrm{As}$ well, in a kind of programmatic hint, we have the-etymologically speaking-oxymoronic phrase "mirabilmente oscura" (Inf. 21.6) just prior to the shipyard simile. If the devils' names are, as has been proposed, punning distortions of known family names - and Dante calls attention to the fact that he learned them all (because he already knew them?; 22.37-39)—we have yet another 
cluster of signals. Virgil himself orertly puns on the word baratteria with his reference to his earlier contention, "baratta," with the devils, to which I return below. Both these words have the potential to recall the learned but semantically unrelated term baratro, the abyss into which we have followed Dante, a term the poet uses somewhat earlier (IIIf. 11.68). Also on the level of nautical wordplay that the reader cannot miss, one of the barrators is pointedly called "vasel d'ogne froda" (22.82; see below).

In support of the claim of a submerged and dispersed complement to the first element of the shipyard simile-effected through lexical duplicity, to tar the procedure with the barrators' brush-a compressed catalogue of these nautical and seafaring allusions now follows. The movement of the boiling pitch is of course not unlike that of the sea itself, with its swelling and subsiding. "Sgagliarda" $(21.27)$ has a faint echo of gagliardetto 'pennant, signal flag' and gagliano, a variant of galeotta 'small galley.' A devil, open wings suggestive of spread sails, shoulder high like the upward angled yard, bears a first sinner like a ship its cargo: "L'omero suo, ch'era aguto e superbo, / carcava un peccator con ambo l'anche" (21.34f.) $)^{27}$ "Anche," as a verse-final word, receives a slight emphasis and, just as it has a phonetic counterpart in the rhyming "Malebranche," it has a second semantic identity in that anco meant 'ship's quarter' and likely, to judge from the Latin term found in Venetian shipbuilding treatises, the parrel tackle on a lateen rig (Martin (217). Carcara is an even more pointed reference to sea-borne cargo. The devil carries the sinner like a carcass, the reference to heel tendons suggestive of the butcher's practice of putting a hook between tendon and hock but also of blocks and tackle. Although carcassa is not attested in Dante, one may wonder whether some of its subsequent meanings 'skeleton of a ship; derelict ressel' were not then already operative. "Ponte" in the following lines is no less a bridge over the infernal sites than the ship's deck and bridge. Virgil's frequent earlier title "maestro" (21.58) now assumes added meaning when we recognize that this was also the term for a ship's master and that Virgil had earlier stood on this same bridge.

Immediately following the scene of the new arrival is the first identification of the sinners here being punished as "barattieri" (41). While individual barrators and a maritime dimension of the term barratry are considered below, we may note the potential for wordplay with barra 'tiller,' not inappropriate since the sinners were financial managers. There is constant reference to graffi, uncini, raffi, all apparently similar to boathooks. A comparison is made with "cuoci" and "vassalli" (21.55) but the former hints at Charon's "cocca" (12.77) and the larger trading vessel known in 
English as a cog, while the latter suggests and anticipates "vasello." In Canto 21 "Che li approda?" (22.78) echoes "proda"; in the next canto at the corresponding point we meet the rhyming phrases "venire a proda" and "vasel di ogne froda." The devil's fart that concludes the canto, a parody of the trumpeter's signal that would have been a normal part of shipboard life, ${ }^{28}$ has, among other referents in the next canto, "nave a segno di terra o di stella" (22.12). This aural cue, which has a counterpart in the barrator's promise, never kept, to whistle up his companions (22.104), concludes the canto and its numerous instances of grim lexical play, both phonic and semantic. We should not neglect the weighted words "nave," "segno," and "stella" in this constellation.

In Canto 22 the ships imagined under repair at the Arzanà are now seen again, as it were at an earlier, risk-filled stage, in the simile of dolphins signaling to sailors to save their ships before an impending storm. ${ }^{29}$ This would not have helped Aeneas and his crew, the objects of Juno's vengeance, nor is such salvation available to the dolphin-like sinners themselves, who were guilty of weakening, not strengthening, the economies in their trust. If any had engaged in the common practice of having ships built with inferior materials or to less than the intended specifications (scantlings), in order to line their own pockets, they may have been responsible for the loss of ships, and thus, in a sense, have occasioned the further work of the shipyard. The sinners half in and half out of the pitch, at times turned head down, resemble ships careened in order to permit crews to work on their hulls. In all of this, land-based similes (rural life, military activity) alternate with references to the sea.

The devils are generally-one might say, superficially-characterized as a military troop but there are occasional examples of their treatment of the sinners as parodies or inversions of the activities of the aryanalotti, and their level of activity is certainly comparable. Although pitch only coats the outside of ships, the barrators are here immersed in it. The verb "disfaccere" is used of dismembering a sinner (22.63); cf. the earlier "fa suo legno nuoxo." The grinding action of the devils (21.134) bears comparison with the hammering of the repairmen on prow and stern ("ribattere"), which is echoed in the beating of wings ("batterò"). ${ }^{30}$ Perhaps the earlier "rintoppa" is recalled the phrase "di rintoppo alli altri" (22.112). One sinner has his skin flayed off (22.41), while patches are added to sails. ${ }^{31} \mathrm{~A}$ devil's tusk rips a muscle from a sinner's arm in a grotesque parody of carving an oar (22.71). The tar-scorched skin of the sinners is likened to a mange ("tigna") which the devils scratch with their hooks (22.93), not unlike the work of scraping barnacles from a ship's hull. 
After another frog simile and with the idiom "renire a proda" meaning "to come ashore" (22.80), the devil Farfarello is called by his leader "malvagio uccello" (22.96), not inappropriate since the devils have wings. The avian imagery continues, with the sinners and devils likened to water fowl and raptors. Then two devils collide in slapstick fashion and themselves fall into the tarpit. Their wings become fouled with the pitch and they must be fished out by their companions. Here it does not seem too far-fetched to observe that while tarring and feathering seems to have had fairly general currency in medieval Europe as an act of shaming and punishment (witness Frate Alberto in Boccaccio's Decamerome), ${ }^{32}$ the earliest reference is in laws promulgated by Richard I of England for the conduct of the fleet that sailed on the Third Crusade, according to which

a robber, moreover, convicted of theft, shall be shorn like a hired fighter, and boiling tar shall be poured over his head, and feathers from a cushion shall be shaken out over his head, so that he may be publicly known; and at the first land where the ships put in he shall be cast on shore." 33

As prisons were a frequent source for pressed seamen, a criminal bent might have been expected, although debtors were preferred, perhaps as more amenable than more violent felons (Lane 1963:198). Parenthetically; we may note that the devils' names are of a kind that might be coined and applied in the all-male environment of a prison, ship, or shipyard. Dante describes the two devils as "mpaniati" and "mpacciati," limed and embroiled $(22.149,151)$, but we are only a few sounds away from penna 'feather; sailyard' and pece. ${ }^{34}$ Here the medium of punishment is, exceptionally, turned back on the punishers and the duplicitous barrators have the last (short) laugh. 35

Some of the claims for and interpretations of putative maritime wordplay may be charged with overreading but I would recall the authorization accorded by Virgil's own pun: "e altra volta fui a tal baratta" (21.63) — a linguistic capability shared by one of the barrators, who, significantly; puns on the word "vasel." Thus, the two most evident instances of paronomasia reference graft/contention and ships, a conjunction to which I return below.

The first lines of Canto 23 bring clarity of vision (the mirror image), a change in mood, a return to univocalism, straightforwardness, reflection. Still, aquatic imagery persists to the end of Dante's sojourn in this part of hell. In a kind of structural recall of the bipartite shipyard simile and of the scene of a winged devil carrying a sinner head down on his back, Virgil now holds Dante upright to his breast as he would a child and slicles down 
the infernal scree on his own back like a ship relaunched down a slipway (carrying a ship's boat?), or water in a sluiceway, which is Dante's explicit comparison (23.46-51).

Viewing the two and a half cantos as a whole, it becomes evident that the past trickery of the barrators, their present attempts at deceit (to escape the devils and con the visitors), the devils' flouting of the agreement not to harm Dante by giving erroneous directions, the parodic matching of infernal punishment to earthly activity, even Virgil and Dante's casuistic accommodation to present circumstance (dealing with devils is summed up in the hypocritical proverb "ne la chiesa / coi santi, e in taverna coi ghiottoni" (22.14f.) - all these have a thoroughgoing but subjacent counterpart in the double-bottomed text where so many maritime and nautical allusions are hidden.

If we have now recognized that in these cantos seafaring and repair may be notions of equivalent importance, have provisionally located the disparate pieces of the second half or tenor of the shipyard simile, and have begun to fit them onto an argument that will be further developed, we may return to our second question, the apparently randomly inventive matching of barrators with tarpits or shipyards.

Romance terms for barratry and its agents display an ambiguous history that seems to share in the word's evolving semantics. Bartering and legitimate commercial contract become overlaid with fraud and deceit, the sale of offices, needless litigation, etc., and even notions of contention and conflict enter the picture, perhaps by way of the Norse-inflected lexis of Normandy. ${ }^{36}$ But in the Italian context semantic contours of baratteria were clearly established by Dante's time and the word is found in the Tesoretto of Brunetto Latini, where it is also a condemnable practice. ${ }^{37}$

In later centuries the Arzanà experienced problems of labor relations, both complaints over the perquisites provided the artisans working there and the extensive misappropriation of construction materials for resale or personal use. ${ }^{38}$ Perhaps it had already acquired a reputation as the scene of embezzlement by Dante's time. But a more direct connection between the barrators and the vehicle of the simile is made with the recognition that barratry was also an explicit concept in the law of the sea. In the specific maritime context, barratry is defined as follows:

Marine Law. Fraud, or gross and criminal negligence, on the part of the master or mariners of a ship, to the prejudice of the owners, and without their consent, e.g., dishonestly sinking, deserting, or running away' with the ship, or embezzling the cargo.

An Italian definition almost seems to have the Commedia in mind: 
Delitto di furto c truffa, il quale si commette vendendo, clandestinamente, parte del carico del proprio bastimento durante la navigazione, appropriandosene il ricavato, studiandosi poscia di far prova d'avaria o di fortuna. ${ }^{39}$

To this we might add that parties other than the ship's owner(s), viz., those who contracted to have cargo freighted, might also be the victims of barratry. After the Rhodian Law of the Sea of late Antiquity; "4 the Tarola Amalfitana from the southern Italian city of Amalfi, dated to ca. 1150, is the first medieval collection of maritime law to make explicit mention of barratry and does so in its third article:

Item pro tarenis quinque, si nauta non habet unde solvat debet carcerari et commictendo barattariam expressam saltim debet carcerari ad arbitrium officialium. ${ }^{41}$

Item a further five tari [a local silver coin], if the mariner does not have the means to pay he ought to be incarcerated; also in the event that he commits evident barratry, he ought without further ado to be incarcerated at the disposition of the officials.

More elaborate codes of maritime law would appear in other cities in the Mediterranean basin: Pisa, ${ }^{42}$ Trani, Venice. ${ }^{43}$ In the western Mediterranean basin, one of the most comprehensive of these was the Catalan Consulat del Mar, which may have taken its presently known evolved form in Valencia in about 1283, that is in Dante's lifetime. In an article dealing with the circumstances under which the master of the vessel shall secure the approval of the shareholders of the vessel before he accepts cargo for shipment, we read:

Mas si lo senyor de la nau serà en loch on no haurà personer algú, ell pot noliejar e anar en tot loc on ell se vulla. E si la nau o leny pendrà algun damnatge, personer algú no li pot fer demanda per aquella raó. Mas si ell ho jugava o baratejava, o.s perdia per algun raó, que fos culpa sua, los personers l.in poden fer demanda. ${ }^{44}$

Howerer, if a master of a ressel finds himself in a territory where none of the shareholders is present, he may use his judgment in accepting an! cargo for shipment to any destination. If the vessel is damaged, none of the shareholders shall make any claims on those grounds. But if the master of the ressel has gambled away; fraudulently sold, or lost the ressel for any other reason for which he is guilty, the shareholders are able to make a claim against him. ${ }^{45}$ 
The French Rôles d'Oléron, named after the island on the route of the wine trade between Bordeaux and England and thought to date from the reign of Richard I, do not mention barratry by name but show a similar concern for fraudulent dealings between masters and merchants. ${ }^{46}$ All merchants and ship's masters of the early thirteenth century would have required some acquaintance with these various codes, whose fundamental legal position as concerns putative crimes committed in extra-territorial waters, as well as closer to home, is quite similar.

Having reviewed historical details of the Arsenal, the features that give Cantos 22-22 particular relief, the explicit signals of wordplay, multiple allusions to ships and sailing, and the recognition of the place of barratry in maritime law, we now turn to individual barrators, still with an eye to nautical and maritime references. Given the foregoing and the two full cantos devoted to them, their presence is at best elusive and shadowy.

The first barrator carried in on the back of a devil is indirectly identified as a Luccan, "un de li anzian di Santa Zita" (21.38). The phrase has an anagrammatic character in keeping with the surrounding wordplay, and anziano, as well as meaning chief magistrate, would also come to mean a lender who had first claim on an estate. ${ }^{77}$ The "Santo Volto" or Holy Face was a Byzantine crucifix in Lucca cathedral but in this context-the pitch pool and the devil's recall of the river Serchio-it has an echo in voltolare 'to roll, wallow,' applicable both to a Luccan swimmer and to a ship in distress. The legal dimension of barratry is emphasized when the devil identifies Lucca as the city where "ita" can be bought to replace a judicial "no." And the irony that figures among the other rhetorical devices which characterize this and the following canto is evident when the devil says that all Luccans are swindlers, save Bonturo, a city boss whom Dante may have actually seen in action.

Dante and Virgil's first personal information comes from an unidentified barrator who served in the household of King Thibault of Navarre. Although Navarre may have lost its earlier coastal towns to neighboring Spanish kingdoms, Thibault's French holdings on the Bay of Biscay, at least, would have included ports. The choice of toponym might suggest nave and the barrator's identification of his father as a "ribaldo" "wastrel' (an economic status with affinities to his own), would call to mind the verb ribaltare 'capsize' if it were so known in Dante's time. "Distruggitor" recalls worn ships, but also the barrator's depletion of resources. With ironic humor, the barrator uses a financial idiom rendere ragione, pay the reckoning, to refer to his punishment.

The barrator does not identify himself by name, and thus trickily eludes absolute inculpation, but, when Virgil asks whether there are 
Italians among them, says he had just seen Frate Gomita, "quel di Gallura, vasel d'ogne froda." The pun on "rasel" (and the echo of "proda" in the rhyme) is better understord when we know that Gallura was a guidicato, judiciary circuit or territorial division, on the island of Sardinia. Its port city; Olbia, called 'Terranoca Pausania in Dante's time, had been rebuilt and settled by Pisans in 1198.48 Frate Gomita's offence was to release Pisan traders guilty of local infractions. This earlicr act now seems mirrored when Thibault's unnamed functionary offers to bring other Italian sinners to speak with Dante and Virgil but fails to deliver. He also names another Sardinian, Don Nichele Zanche, a judge of Logodoro, with whom Iirate Gomita is still engaged in the discussion of Sardinian affairs.

Barratry; along with Zanche, is recalled at end of Canto 33 of Inferno, where we learn of a barrator, Branca d'Orio, whose soul was condemned to punishment in hell when he was still alive, while a devil occupied his body on earth. He had assassinated Zanche, his father-in-law, and his commitment to hell before death seems the inverted counterpart of the Navarese barrator who momentarily escapes punishment after death. Dante's own close brush with barratry, on earth and in hell, also joins this cluster of references. The fact that barratry, through such explicit mention and the rare instance of a flashback to the fifth bolgia, should be recalled within 200 verses of the close of Inferno seems to bear out the clain for the marked and highly personal nature of Cantos 21 and 22. From this perspective, Malacoda's signal fart, at the cusp between these two cantos, can be seen to point ahead to Virgil and Dante negotiating Satan's rump to begin the climb of Mount Purgatory.

Yet it must be recognized that Dante's contact with these sinners is very cursory, unlike the threat of the devils. With only one direct speech, there is little hint of, or appeal to, psychology or conscience. None of the damned, all from cities other than Florence, elicits emotional or intellectual engagement from Dante the Florentine. In short, the closest the notion of barratry here comes to Dante's prior life and to his city is in two similes, the first conjuring up troops marching out of the castle of Caprona under a treaty with Florentine and Luccan forces, the second, military scouts from these same two city states deployed before Arrezzo. If Dante were present at the defeat of Arrezzo, as is conjectured, his relation to the conquered would have been roughly that of his present circumstances visà-vis both sinners and devils-close but not too close.

Comparable to the barrators who are not particularly memorable (although this point has not often been made), the Venetian shipyard simile, as traditionally viewed, seems remote from the central issues of the 
poem, even from the sinners and their punishment. Once we recognize that barratry was a crime addressed by the maritime law of Dante's time, the simile seems relevant but perhaps no more than adequately so. Yet in the light of the Commedia's larger thematic configuration of life and artistic endeavor as voyages on true and false courses, the poet as mariner, poem as ressel, spiritual rehabilitation, the many signposts in Cantos 21 22 for the reader's attention, and the personally charged circumstances of Dante witnessing divine retribution for the crime with which he had himself been charged-in light of all this, the scene of the Arzanà and the consequent maritime allusions must be seen as invested with additional, indeed, vital significance.

Over a narrative and descriptive course of more than two cantos, Dante the pilgrim proceeds fearfully, cautiously, inconspicuously, yet safely through the zone of hell reserved for grafters, swindlers, embezzlers, a company to which the city of Florence had committed him. But Dante the poet, now a skilled defence lawyer in a court he cannot avoid ("l'uom cui tarda / di veder quel che li convien fuggire"), devises an audacious rhetorical strategy to exonerate his client without ever dignifying the fraudulent charge with explicit mention. In an environment with salvific overtones, Dante's procedure is to maintain intellectual and emotional, if not full physical, distance from the culpable and thus from culpability. There is no meaningful engagement with any of the damned. Proximity can be dared because it does not entail or imply association. Dante keeps our attention on exteriors, on visual and acoustic impressions, even as he invites us to complete the opening simile and pursue maritime allusions, diversions like the grotesque effects of the devils' behavior perhaps intended to preclude other reflection. The poet sails close to the lee shore of these sinners by appropriating their techniques (the instances of duality; repetition, inversion, punning, etc.), reflecting the unnamed barrator's claim to "lacciuoli a gran divizia" (22.109), while audaciously locating the truly condemned barrators in a context resonant with the privileged Dantean metaphors of seafaring. Recalling the distinction "non per fuoco ma per divin' arte" (21.16), Dante skilfully turns double-dealing back on his accusers, just as the Navarese sinner embroils the devils.

Continuing on his course of learning and revelation, Dante leaves the barrators' bolgia and its pool of pitch unscathed-immaculate we might say-a citizen in exile but no criminal, an artist still bold as Ulysses and, under the sure hand of his master, a progressively sounder vessel for the Christian spirit. 


\section{NOTES}

${ }^{1}$ Dante Alighieri, Inf. 21.7-21; translation adapted, in particular as concerns nautical terms, from Sinclair (1959). The new editions by Lanza and Sanguincti bring no proposed amendments to this passage.

'I ansing 1977:61f., with "asymmetrical simile" at 38. See, too, Applewhite 1964. For a succinct survey of critical comment on Canto 21, sec Ellis 1998, to which we may add Picone 2000.

"To cite only the last-named of these, L'Espurgatoire Seint Patriz, "Cinquième tourment," rv. 1097f:: "asquans en vit mis en es peiz e rostis od souphre e od peiz."

${ }^{4}$ lorbes 1936; on quagmires and surface deposits in the Middle East, see pp. 23-27, and for the waterproofing mineral pitch called bitumen judaïum, pp. 85-87. On early caulking, see Basch 1986. The preserved remains of animals trapped in the tar pits, if this phenomenon were known in the west, would be a further incitement to associate tar with the damned.

5From Arabic qalfata 'to caulk' and dar-stina'a 'factory', respectively: See Pellegrini 1972: 423f. Referencing the boiling pitch of the Arsenal in the infernal context could also call to mind French arser, Provençal arsar 'to burn.' On this canto as a locus for extensive paronomasia, see below:

${ }^{6}$ Early Italian references are found in "Conto navale pisano," 1982:3-6, and in the late thirteenth-century translation of Vegetius (1815:180).

'Quoted in Guyotjeannin and Nori 1989:320. These authors call attention to clauses in mid-thirteenth century contracts from Pisa and Genoa that in respect of caulking, construction, sails and gear are "di una precisione quasi maniacale" (316).

${ }^{8}$ Martin 2001, Fig. 115, 129, and commentary, 127.

${ }^{9} \mathrm{By}$ the early fourteenth century, the Republic of Venice was subsidizing merchant galley convoys to Flanders, northern Europe, Syria, Cyprus, Romania, and Alexandria. For early examples of regulations, see Gli statuti marittimi veneziani fino al 12551903 . Despite early standardization in the construction of vessels, the oldest manuscript of the Fabrica di galere, a treatise on construction, dates from about 1500; see Jal 1840, vol. 2, "Némoire 5," with an important corrective and complement in Anderson 1945. For concise accounts of construction principles based on the most recent archaeological finds, see Hutchinson 1994:36ff. Of the extensive literature on V'enctian ships and shipping, see in particular Lane 1963 and 1934, and Rubin de Cervin 1985.

10Delaney 1983:303, Kaftal 1978:429. Perhaps in anticipation of these spatial arrangements Dante in Canto 19 employs the personal anecdote of breaking a baptismal font to save a drowning infant as the basis for a comparison of the bolge (19-21).

$11 \lambda$ good example of a ship careened prior to repair is found in a detail from The Judgment of Paris by the School of Botticelli (ca. 1445-1500); reproduced in Rubin de Cervin (14) and Martin (124). Although the three-masted ressel with 
mixed rig provides a useful orientation for a consideration of Dante's text, it represents a later evolution, a cocbe on the way to becoming a carrack (Martin 123ff.).

12 As concerns the terminology of naval architecture, Dante's vocabulary seems to be that which was in everyday use, to the extent that this is recorerable; see the glossary of Venetian and Latin terms in Martin (217-21), and references there to studies by Chiggiato, Corazzini, and Pryor.

${ }^{13}$ Martin (177). Martin makes the useful point that in the Venetian consciousness, reference to a ship always called up a merchant ressel. Ships built exclusively for warfare were rare, but merchant vessels were designed for rapid accommodation to military deployment.

${ }^{14}$ The nautical vocabulary in Virgil's first book in addition includes: anchora 'anchor,' latus 'side' (including "compagibus laterum," 'closures of the sides'), magister 'pilot,' morsus 'anchor fluke,' navis 'ship, puppis 'stern, stern deck,' prora 'prow, remus 'oar,' midens 'rope,' tabula 'plank,' velum 'sail,' vinculum 'cable.'

${ }^{15}$ Lansing sees a rather different Virgilian inspiration: "the ... model for describing diversity of action within uniformity of purpose, evident in the bee and ant similes" (1977:61).

${ }^{16}$ Hollander 1984; for a rather different take, see Ryan 1982.

${ }^{17}$ See, among other commentators, Baglivi and McCutchan 1977.

18 As concerns the relative position of this scene and the architectonics of the canticle as a whole, the numerical ratio between Cantos 22-34 and Cantos 1 21 is the same as that between Cantos 1-21 to the whole of Inferno, very nearly 3:5, an illustration of the Golden Mean.

${ }^{19}$ A point early made by Croce; see Ellis 1998:293. Although now a bit dated, see Orengo 1969, in particular as concerns Canto 21, "Con Dante, nell'Arzanà," Pt. 2, Ch. 7, 201-16.

${ }^{20}$ Discussed in Lansing 1974 and recapitulated in Lansing 1977.

${ }^{21}$ Evans 1966:1-5, citing Curtius 1963:138-41.

${ }^{22}$ The mention of the dark wood at the close of Canto 20 (129) recalls the path motif, just a few verses before the presentation of the Arzanà.

${ }^{23}$ Clysses has been the subject of extensive comment. See, most recently; Orsini 1985 and Barolini 1997.

${ }^{24}$ See, among other commentators, Battistini 1997.

25 If we view some of the barrators as devious financial managers, bolla could be claimed to pun on bolletta 'bill, receipt.'

${ }^{26}$ Other lexical cues are "aspetto fero," v. 31, "mi parea," v. 32, "sembianza," v. 99; see De Robertis 1981. This while Dante himself is at times crouched out of sight.

${ }^{27}$ This notion is well illustrated in John Flaxman's drawing from 1793, reproduced in Nassar 1994:251. The scene may also be read as a parody of the Good Shepherd carrying a sheep; Kleinhenz 1982. As well, the devils may be seen as corsairs bearing God's letter of marque. 
${ }^{28}$ See Pardessus 1828-45:5.30.28. In the absence of modern critical editions, this monumental collection remains invaluable for an initial orientation to the subject, but the individual codes reproduced and translated must be considered with great caution in philological, juridical, technical, and editorial respects.

${ }^{29}$ Venetian shipbuilding treatises referred to the curvature of the hull and prow above the water line, called the rake in English, as lanqar in delfimus; Martin (175).

30 No allusion to a ship beating or tacking into the wind should be inferred here, as English beat in this sense is derived from Norse beita 'to bite into.'

${ }^{31}$ The English idiom "rip off," profiting through financial deception, makes us wonder whether the popular Italian of Dante's era did not have many other terms for fraud (or, for that matter, nautical manoeuvres) that are mirrored in the text but perhaps not susceptible to recovery. On the relatively high incidence of (Florentine?) slang in these cantos, see Ellis (287f.).

${ }^{32}$ In the second novella of the fourth day, Frate Alberto is covered with honey and down for impersonating the archangel Gabriel in order to trick Madonna Lisetta. Other European examples include the 'Tannhäuser legend and a variety of Scandinavian tales.

${ }^{33}$ Roger of Hoveden 1868-71:III.36.

${ }^{34}$ The contract between Venice and the crusaders makes the first mention of seamen called permese (here pomnesi). These were highly skilled mariners responsible for the vital and fairly complex manoeuvres with the tiller, yards (penne), sails, and riggings. They had preferential status on board and separate quarters; Guyonjeannin and Nori $(320$, n. 4).

${ }^{35} \mathrm{On}$ various aspects of deception within the canto, see Bosco 1975, Falvo 1987, and Kleinhenz 1989.

${ }^{36} \mathrm{~A}$ full discussion of the etymology and early history of Romance terms for barratry (and of the lack of consensus among lexicographers) cannot be undertaken in the present context. The most recent attempt at an overview is found in Lessico etimologico italiano (1997-), Vol. 4, s.u. baro. Despite the value of this wideranging review, the referral of baratteria and myriad other terms to baro, both 'man' and 'rogue,' does not convince (cols 1433ff.). Garzanti etimologico 2000 refers baratteria first to a Provençal term and then to a Norse origin, a gross simplification. But for the proposed and plausible interference of a Norse loan in northern French lexis, see de V'ries 1962, s.r: baratta 'Streit' (< berja + atta), and ron Wartburg, Vol. 8 (1959), 330ff., s.r. prattein.

${ }^{37}$ Latini 1960:II.216; cf. Fiore 1984:256.

38 Although he deals with a somewhat later period, one may consult with value Davis 1991 and 1997.

${ }^{39}$ Dizionario della lingua italiania 1861-79:B-C.864.col. b.

${ }^{40}$ Nomos Rbodon nautikos. The Rbodian Sea-lan', 1909. These statutes, which took form between 600 and 800 , show a concern for watertightness among other 
legal considerations; see "Introduction," clxxxiv, and 183, for a discussion of tow and pitch expenses. Islamic law, which might be thought to have had some influence on codes developing in the West, if only as a result of trade contact, in principle makes little difference between crimes committed on land and those committed at sea. Fraud and embezzlement are not specifically addressed in maritime codes and pronouncements, although wilful damage to cargo is; see Khalilieh 1998.

${ }^{41}$ Tabula de Amalpha 1965:35ff.

${ }^{42}$ Constituta legis et usus pisanae civitatis... 1870. Statuti inediti della città di Pisa dal XII al XII' secolo 1854-70:I.305f, also has a reference to the importance of caulkers.

${ }^{43}$ Early Venetian tracts, with their sponsors and dates (Ziani, 1227, Tiepoli, 1229-36, Zeno, 1255) are briefly characterized in Ashburner's "Introduction" (Nomos Rhodon nautikos 1909:cxixff.). Subsequently, the mercantile term baratteria was widely disseminated in the eastern Mediterranean, principally by Italian traders, and appears in both Turkish and Arabic; see Kahane, Kahane and Tietze 1958:91.

${ }^{44}$ Libro del consulado del mar: 1965:art. 228.456. Watertightness and seaworthiness generally are also emphasized in the code. The edition is based on a manuscript of the fifteenth century. To cite only a single commentary on this code, see Villain-Gandossi and Larrère 1983.

${ }^{45}$ The translation is lightly adapted from Consulate of the Sea and Related Documents 1975:art. 229.127; Jados translates baratejara as 'squandered,' by which he perhaps means 'injudiciously appropriated-and lost.' Barratry is also mentioned at several other points in the work.

${ }^{46}$ For the text, see Pardessus. A recent study is Peyronnet 1986. Local adaptation were made in Britain, e.g., as preserved in The Oak Book of Southampton 1910 , and early maritime codes from Newcastle-upon-Tyne and lpswich.

47"Sono pagati primo i servitori e marinari del detto vaso della loro mercede ... e sono anziani ad ogni altra sorte di credito," Dizionario della lingua italiana 186179: A.492.col. b. The abbreviation Cons. Mar. 33, is not expanded in the listing of sources in the final volume of this work.

${ }^{48}$ The inland town of Arzana is not too far distant.

\section{W'ORKS CITED}

Alighieri, Dante. I a Commedia secondo l'antica mulgata. Ed. Giogio Petrocchi. Vol. II, Inferno, vol. III, Purgatorio, vol. IV', Paradiso. Verona: Mondadori, 1966-67. . Dante's Inferno: Italian text with English translation and comment. Trans. John

D. Sinclair. New York: Oxford University Press, 1959.

Fiore. In I/ Fiore e il Detto d'Amore attribuibili a Dante Aligbieri. Ed. Gianfranco Contini. Milano: Mondadori, 1984.

Anderson, R. C. "Jal's 'Mémoire No. 5' and the Manuscript of 'Fabrica di galere'." The Mariner's Mirror 31 (1945):160-67. 
Applewhite, James. "Dante's L'se of the Extended Simile in the Inferno." Italica 41 (1964):294-309.

Baglivi, Giuseppe, and Garrett McCutchan. "Dante, Christ, and the Fallen Bridges." Italica 54 (1977):250-62.

Barolini, Teodolina. "Dante's Ulysses: Narratice and Transgression." In Dante: Contemporary Perspectires. Ed. Amilcare Iannucci. Buffalo and Toronto: University of 'Toronto Press, 1997. Pp. 13-32.

Basch, Lucien. "Note sur le calfatage: la chose et le mot." Archaeonantica 6 (1986):187-98.

Battistini, A. "L'arte d'inabissarsi, o la retorica della 'tenace pece' (Inf. XXI)." L'Alighieri: Rassegna bibliografica dantesca, n. s. 9 (1997):73-92.

Bosco, Umberto. "ll ludo dantesco dei barattieri." In Essays in Honour of John Humploreys II biffield. Ed. H. C. Davis et al. London: Department of Italian, University of Birmingham, 1975. Pp. 30-40.

Concina, Ennio. L'Arsenale della Republica di I 'enezia. Milan: Electa, 1988.

Constituta legis et usus pisanae ciritatis... Ed. Francesco Bonaini. Pisa: Florentiae, 1870.

Consulate of the Sea and Related Documents. Trans. Stanley S. Jados. University; Alabama: University of Alabama Press, 1975.

Conto navale pisano. In La prosa italiana delle origine: I. Testi toscani di carattere pratico. Ed. Arrigo Castellani. Bologna: Pàtron, 1982.

Curtius, Ernst Robert. "Schiffahrtsmetaphern." In Europäische Literatur und lateinische Mittelalter: 4th ed. Bern and München: Francke, 1963. Pp. 138-41.

Davis, Robert. Sbipbuilders of the I enetian Arsenal: IVorkers and Workplace in the Preindustrial City. Baltimore: Johns Hopkins University Press, 1991.

"Venetian Shipbuilders and the Fountain of IVine." Past \& Present 156 (1997):55-86.

Delaney, John J. Dictionary of Saints. New York, Garden City: Doubleday and Company, 1983.

De Robertis, Domenico. "In viaggio coi demòni (canto XXIl dell'Inferno)." Studi danteschi 53 (1981):1-29.

Dizionario della lingua italiania. Eds Nicolò Tommaseo and Bernardo Bellini. 4 vols. Torino: Unione tipografico-editrice, 1861-79.

Ellis, Steve. "Canto XXI: Controversial Comedy." In Lectura Dantis: Inferno. Eds Allen Mandelbaum, Anthony Oldcorn, and Charles Ross. Berkeley: University of California Press, 1998. Pp. 287-96.

L'Espurgatoire Seint Patriz. Ed. Yolande de Pontfarcy: Louvain, Paris: Peeters, 1995. Evans, Arthur R., Jr., "A Nautical Metaphor in Dante and Claudel." Romance Notes $8(1966): 1-5$.

Falvo, J. "The lrony of Deception in Malebolge: Inferno XXI-XXIl." Lectura Dantis 2 (1987):55-72.

Forbes, R. J. Bitumen and Petroleum in Antiquity. Leiden: E. J. Brill, 1936.

Garzanti etimologico. Eds Tullio De Mauro and Marco Mancini. I Grandi Dizionari. Milano: Garzanti linguistica, 2000. 
Guyot, Olivier, and Gabriele Nori. "Venezia e il trasporto dei crociati. A proposito di un patto del 1219." Studi Medierali 30 (1989):310-21.

Hollander, Robert. "Virgil and Dante as Mind-readers (Inferno XXI and XXIII)." Medievo romanzo 9 (1984):85-100.

Hutchinson, Gillian. Medieval Sbips and Shipping. London and Washington: Leicester University Press, 1994, repr. 1997.

Jal, Augustin. Arcbéologie navale. 2 vols. Paris: Arthus Bertrand, 1840.

Kaftal, George. Iconograplyy of the Saints in Nortbeast Italy. Florence: Sansoni Editore Nuove, 1978.

Kahane, Henry, Renée Kahane, and Andreas Tietze. The Lingua Franca in the Levant: Turkish Nautical Terms of Italian and Greek Origin. Urbana: University of Illinois Press, 1958.

Khalilich, Hassan Salih. Islanic Maritime Lan: An Introduction. Leiden and Boston: Brill, 1998.

Kleinhenz, Christopher. "Deceivers Deceived: Devilish Doubletalk in Inferno 21 23." Quaderni d'Italianistica 10 (1989:133-56.

. "Iconographic Parody in Inferno." Res Publica Litterarum: Studies in the Classical Tradition 5 (1982):125-37.

Lane, F. C. T'enetian Ships and Sbiphwilders of the Renaissance. Baltimore: Johns Hopkins Unirersity Press, 1934.

"Venetian Merchant Galleys 1302-1334: Private and Communal Operation." Speculum 38 (1963):179-205.

Lansing, Richard H. "Two Similes in Dante's Commedia: The Shipwrecked Swimmer and Elijah's Ascent." Romance Pbilology 28 (1974):161-67.

. From Image to Idea: A Study of the Simile in Dante's "Commedia". Ravenna: Longo Editore, 1977.

Latini, Brunetto. I/ Tesoretto. In Poeti del Drecento. Ed. Gianfranco Contini. MilanoNapoli: Ricciardi, 1960.

Lessico etimologico italiano. Ed. Max Pfister. Wiesbaden: Reichert, 1997-.

Libro del consulado del mar. Edición del texto original catalan y traducción castellana. Ed. and trans. Antonio de Capmany. Barcelona: Cámara oficial de Comercio y Navegación de Barcelona, 1965.

Martin, Lillian Ray. Art and Arcbaeology of I'enetian Sbips and Boats. College Station: Texas $\Lambda$ \& M U niversity Press, 2001.

Nassar, Eugene Paul. Illustrations to Dante's Inferno. Cranbury, NJ: Farleigh

Dickinson University Press and Associated University Presses, 1994.

Nomos Rbodon nautikos. The Rhodian Sea-law. Ed. and trans. Walter Ashburner.

Oxford: Clarendon Press, 1909.

The Oak Book of Southampton of C.A.D., 1300. Ed. and trans. Paul Studer. 3 vols. Southampton: Cox and Sharland, 1910.

Orengo, Rinaldo. Le arti del mare in Dante. 2nd ed. Roma: G. Volpe, 1969.

Orsini, André. "L’Ulysse de Dante et la Néditerranée." In L'bomme méditerranéen et la mer. Eds Micheline Galley and Leila Ladjimi Sebai. Tunis: Salammbô, 1985. Pp. 522-29. 
O.ford English Dictionary. 2nd ed. prep. by J. I. Simpson and E. S. C. IVeiner. Oxford: Clarendon Press, New York: Oxford Lniversity Press, 1989.

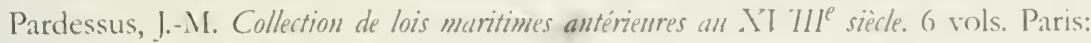
Imprimerie royale, $1828-45$.

Pellegrini, Giovanni. Gli arabismi nelle lingue neolatine: con speciale riguardo all ltalia. Brescia: Paidica, 1972.

Peyronnet, Georges. "Un document capital dans l'histoire du droit maritime: les rôles d'Oléron, XII-XV'll siècles." Sources [Paris] 8 (1986):3-10.

Picone, Michelangelo. "Canto XXI." In Lectura Dantis Turicensis: Inferno. Eds Georges Güntert and Michelango Picone. Turin: Franco Cesati Liditore, 200(). Pp. 291-304.

Roger of Hoveden. Chronica magistri Rogeri de Honedene. Ed. William Stubbs. 4 vols. London: Longman et al., 1868-71. [Rolls Series 51].

Rubin de Cervin, G. B. La Flotta di I'enezia: Nani e Barche della Serenissima $=$ The I enetian Fleet: Ships and Boats of the I'enetian Republic. Milano: Automobilia, 1985.

Ryan, Christopher J. "Inferno XXI: Virgil and Dante: A Study in Contrasts." Italica 59 (1982):16-31.

Statuti inediti della città di Pisa dal XII al XII' secolo. Ed. Francesco Bonaini. 3 vols. Firenze: G. P. Vieusseux, 1854-70.

Gli staturi marittimi veneqiani fino al 1255. Eds Riccardo Predelli and Aldolfo Sacerdoti. Venezia: Prem. stab. tip.-lit. Visentini cav. Federico, 1903.

Tabula de Amalpha. Eds and trans Enrico D'Auria and Vincenzo Giuffrè. [Amalfi]: Di Mauro, 1965.

Vegetius. Dell' arte della guerra di I'egezio Flavio volgarizzata libri II : Trans Bono Gaimboni. Ed. Francesco Fontani. Firenze: Marenigh, 1815.

Villain-Gandossi, Christiane, and Jean-Jacques Larrère. "Le 'Llibre del Consolat de Mar': les gens de mer, leurs droits et leurs obligations." In Actes du 106e Congrès national des Sociétés sarantes, Perpignan 1981. Paris: Bibliothèque Nationale, 1983. Pp. 153-67.

de V'ries, Jan. Altnordisches etymologisches II örterbuch. 2nd rev: ed. Leiden: E.J. Brill, 1962.

von Wartburg, Walter. Französisches etymologisches W"̈̈rterbuch. 20 vols. Bonn: Klopf, 1928-68, since 1992 Basel: Zbinden. 